Actinozoa. These " are distinct from the Spongida, although some synthetic-minded morphologists classify all together as Cœlenterata." In treating of the fresh water Hydra we notice the "old story" repeated that "if the body be turned inside out, the old ectoderm [why the adjective?] takes on the digestive power and the former endoderm that [takes on the function] of the skin."

The order Hydrocorallina is placed as the last of the Hydrozoa, with the families Milleporidæ and Stylasteridæ, as indicated by Moseley, to whose researches and those of Agassiz we are indebted for all we know about the order. Millepora alcicornis was obtained by Moseley at Bermuda. The calcareous tissue of the coral is very hard and compact, and the polyps are extremely small. It is very difficult to prevail on the polyps to protrude themselves from their cells, but Mr. J. Murray, of the Challenger Expedition, succeeded in procuring them in this state on two occasions, and the accompanying drawing (Fig. 2) of one of the expanded polyps, and of five of its surrounding zooids, is from Mr. Moseley's memoir on the structure of this genus. In the centre is seen the short polyp form provided with a mouth and with only four short knobby tentacles, while grouped around are the five polyps without mouths, and for the sake of letting the central zooid be clearly seen a sixth mouthless zooid is omitted from the sketch ; these latter zooids have from five to twenty tentacles; they are much more active than the mouth-bearer, and do the work of catching food for it. When alarmed all disappear within the framework.

The article on the group of the Sponges is excellent. The author now regards the sponges as forming a separate class independent of the Colenterata, and situated at the very bottom of the Metazoic sub-kingdom, and gives a brief sketch of the orders and sub-orders.

The figures of sponge structure are refreshingly new, many of them being from quite recent sources--such as the memoirs of Haeckel, Schulze, and Prof. Sollas himself. The beautiful sponge belonging to the genus Euplectella, now known to live anchored in the mud in deep seas, or attached to the hard bottoms of shallower waters, has had its structure ably described by Prof. Schulze, from whose memoir the annexed woodcut (Fig. 3 ) is taken. The membranous wall-very delicate and thin-which surrounds the skeleton is furnished with smooth-edged roundish pores of different sizes, irregularly arranged, and varying very much in number. These form an open communication between the cavities of the chambers and the ductlike spaces surrounding them, which penetrate everywhere between the ciliated chambers and extend even to their mouths, where they terminate on a tougher membrane, which binds together and connects laterally the chamber walls. The figure shows the outer portion of a thin section taken perpendicularly to the outer surface through the side wall of a ridge, and is magnified $\times 150$. Several of the ciliated chambers are seen.

Although the Rhizopods are described as standing "first in the scale of animal organisation," we find them treated of in a chapter before that relating to the Infusoria, and we are told in the same paragraph that "they have in a great degree the same simple constitution as several other kinds of animalcules which are grouped by naturalists as Protozoa." We venture to think that such a description will be apt to lead the general reader astray ; nor was it quite fair of the Editor to allow the writer of the article on the Rhizopods to go somewhat out of his way in his forty-ninth paragraph to give a view of the organisation of the Sponges which will be apt to puzzle the reader who has perused the more accurate account of the sponge structure given by Prof. Sollas.

As an example of the beautiful illustrations of the Infusoria, which are for the most part taken from Saville Kent's excellently illustrated Manual of Infusoria, we give the woodcut of Rhipidodendron splendidum. There are
few workers with the microscope who devote themselves to the study of the Infusoria but must be familiar with the stems of that group of animalcules, which gravitate about the well known Anthophysa vegetans of Muiller; the attached colony stocks putting one in mind of some minute fucoid stem. Of this group the species figured after Stein is one of the most remarkable, originally described and most beautifully illustrated in Prof. Stein's great work. This freshwater form has apparently not yet been found in this country, but a nearly allied species, R. Huxleyi, has been met with in South Devon. The figure shows the compound colony stock at $A$, the quite young colony stock at $B$, which latter was built up by a single monad, which divided by longitudinal fission, producing two parallel, or nearly so, tubes, and one of these monads is seen at $C$ free, without a tube.

In congratulating the Editor on the successful termination of his labours, we are not unmindful of the difficulties he has had to encounter in trying to secure a more or less uniform style of treatment of subjects so varied as the different classes and sub-divisions of the animal kingdom.

\section{THE CONDENSATION OF LIQUID FILMS ON WETTED SOLIDS}

IN Poggendorff's Annalen for 1877, and in the Philosophical Magazine for I880, I have recorded some facts which are satisfactorily explicable only on the supposition that the liquid in contact with the glass undergoes condensation upon the surface of the latter. In the latter paper I was able to show that this condensed film visibly altered the resistance experienced by the liquid in flowing through the tube. In the paper in the Poggendorff's Annalen it was shown that a difference of potential was set up between the two ends of a capillary tube through which water was forced, and that the effect of leaving the water in contact with the tube was that this difference of potential rapidly diminished. No doubt this finds its explanation in the effect of the condensation of the liquid on the sides of the capillary tube, causing the friction of the water against the tube to become less and less, whilst the friction of the water upon the condensed water-film becomes progressively greater, as the latter adheres more strongly to the glass. Probably simple drying would suffice to restore to the tube the originally observed difference of potential between its ends.

Whilst working upon this subject I noticed the large E.M.F. produced by a small air-bubble slowly ascending through the vertical capillary tube which was full of water (see Dr. Dorn, Ann. d. Phys. u. Chem. I880, S. 73). At the time I could not account for this, but not Jong ago I constructed an apparatus which allowed of alternate drops of water and bubbles of air being driven through the capillary tube. This produced a very large E.M.F. Probably this increase in the E.M.F. is dependent upon $(a)$ the increased electrical resistance consequent upon breaking up the water in the tube into drops separated by air-bubbles, and $(\beta)$ upon an increased disturbance of the liquid film adhering to the glass. Experimentally these effects, $(a)$ and $(\beta)$, might be separated by substituting for water a (practically) perfectly insulating liquid.

Another and very interesting illustration of a liquid condensed on the surface of a solid is probably to be seen in the familiar fact that water will not clean a greasy sheet of glass.

As is well known to all workers on surface tension, almost the only way of getting a physically clean surface of glass is by heating the glass in concentrated sulphuric acid, to which a little nitric acid has been added, and then heating, after washing in pure water to remove the acid. Such a glass surface exposed to the air for a short time is generally imperfectly 
wetted by water. This no doubt arises, partly at least, from the condensation of gases on the surface, which Quincke has shown will produce this effect to a remarkable extent under certain conditions described by him. To this, also, Barrett and Stoney have referred certain modifications of Leidenfrost's phenomena ; and the floating shells, \&c., of Hennessey are due to the same general cause. But a very minute trace of oil on a physically clean surface produces the familiar greasy surface. Why is this? Oil is not insoluble in water, and when the quantity of water used is sufficient to dissolve the quantity of oil placed on the glass, it ought to wash off. Every one knows, however, how difficult it is to wash oil off glass. Is this then due to a diminution in the solubility of the oil in the water owing to its CONDENSATION on the glass surface? I believe it to be very probable that this is the case, and think that the experimental proof would be possible by placing estimated quantities of oil on a physically clean glass surface, and subsequently washing in quantities of water, such as under ordinary circumstances would readily suffice to dissolve it. By dissolving the oil in a volatile medium, its quantity might be readily estimated. No doubt other liquids of somewhat greater and better known solubility might be advantageously substituted for the oil, and perhaps, as Dr. Japp has suggested to me, by employing a coloured liquid the result might be rendered evident to the eye.

My inability to complete these experiments at the present time, and the great interest attaching to a determination as to whether the condensation experienced by the liquid-film alters the physical or chemical properties of the liquid must be the excuse for the publication of incomplete results, which I much hope may be taken up by others.

J. W. CLARK

\section{THE STOCKHOLM ETHNOGRAPHICAL EXHIBITION}

D

R. STOLPE was asked to arrange and describe the Ethnographical Exhibition of Stockholm in the year 1878 . This exhibition was brought together from all, or at least nearly all, Swedish public and private collections; no less than 217 exhibitors with about 10,000 objects participated, the King himself opened the galleries, and general interest was raised by an ethnographical exhibition as indeed no other country has realised till now. We took occasion to visit the exhibition, and were astonished to see so rich a material, as well as a thoroughly scientific arrangement.

Both works named below are a result of the meritorious undertaking. The second was partly a guide through some parts of the exhibition, especially China and Japan, with a general introduction, and many valuable and interesting special remarks, partly, in its second volume, a determination of all, about 6200 numbers of the exhibition, arranged after the exhibitors. The first-named work illustrates in geographical order the more important objects of the exhibition, partly in groups, but chiefly in single representations. There may be represented in all about I 500 objects, and we hear that a fourth supplementary volume is in the press.

The first volume of this album contains, on 84 plates, Australia, Oceania, Malaysia, Madagascar, Malayo-Chinese, and Tibet; the second, on 116 plates, China, Japan, Samoyedes, and Turks; the third, on 78 plates, America, Africa, Circassia, Persia, and India. Japan and China, as well as Oceania, are relatively best represented; among the last-named division figures the fine collection from the Savage Islands, which the expedition of the Eugenie brought home in the year 1853 .

r H. Stolpe, "Exposition ethnographique de Stockholm, 1878-r879." Photographies par L. F. Lindberg. 3 vols. 4to. 36 pp. $27^{8}$ plates. (Stockholm, 188r).- "Den allmänna etnografiska utställingen, 1878-1879" (The General Ethnographical Exhibition). 2 vols. 8 vo. 80 pp. 1878-1879, and viii. II2 pp. 1880 .
This photographic album must be regarded as the best existing ethnographical atlas; it gives, notwithstanding the inequality in the representation of the single countries, a good idea of a high-class ethnographical museum. The editor has had a full appreciation of the problem which was to be solved, and no ethnologist who works scientifically can do well without this album. It was therefore right that the International Geographical Congress of Venice in the year $188 \mathrm{I}$ should bestow a prize on this beautiful work. Copies of the album are, we believe, only printed to order, and may be obtained direct from Herr Lindberg, R. Archæological Museum, Stockholm.

\section{A. B. MEYer}

\section{BARON MIKLOUHO-MACLAY}

ETTERS have been received from Baron $N$. de Mikloubo-Maclay from the Suez Canal, the distinguished traveller being now on his way back to Australia. During his prolonged and arduous experience of eleven years' life amongst Melanesian and other savages of the Pacific his health has, we are sorry to say, suffered very seriously, and he returns to Sydney mainly on this account, since he finds that the climate of New South Wales suits him best. He intends to call at Batavia on the way out, where he left a part of his collections in 1878 , in order to convey these to Sydney, where the main bulk of the gatherings of his many journeys is already stored. The Emperor of Russia, with enlightened liberality, has promised to defray the cost of the publication of the scientific account of Baron de Maclay's results, and the collections have been brought together at Sydney in order that they may be available for the preparation of the work for the press there.

Baron de Maclay hopes to be able to get ready the whole of his numerous diaries, notes, and papers for publication in about two years' time. The complete work to be issued by him will, if his present plan be carried out, consist of an anthropological and ethnographical section, a section treating of comparative anatomy, and a general narrative of his travels, together with appendices containing meteorological observations and information on physical geography.

The work will be published first in Russian, but translations in other languages will probably soon follow.

He intends to do a good deal of the anatomical work needed to complete his researches on animals collected by him in Australia and New Guinea at the Zoological Station at Watson's Bay, of which he is the founder. This Zoological Laboratory at the very first received most important support from the Linnean Society of New South Wales, and by the influence of this Society a grant of land was obtained from the Ne:v South Wales Government for the erection of the building. Scientific men in other colonies, and notably in Victoria, recognising the great imporiance of the establishment to the progress of biological research, have come forward nobly to support the enterprise, and the Australian Biological Association has been formed, a Society including men of science of all the Australian colonies and some distinguished European naturalists, the object being to support biological stations in Australia. It is very gratifying to find so enlightened a sympathy with scientific progress developed, and that the different colonies are able to work together in so excellent a cause. We hope to refer shortly again to the constitution and aims of the Australian Biological Association.

\section{NOTES}

WE can only for the present express the deep regret with which we learn of the death, on the 9 th inst., of Prof. H. J. S. Smith, of the Savilian Chair of Geometry at Oxford, at the 